DOI:10.17951/h.2017.51.3.115

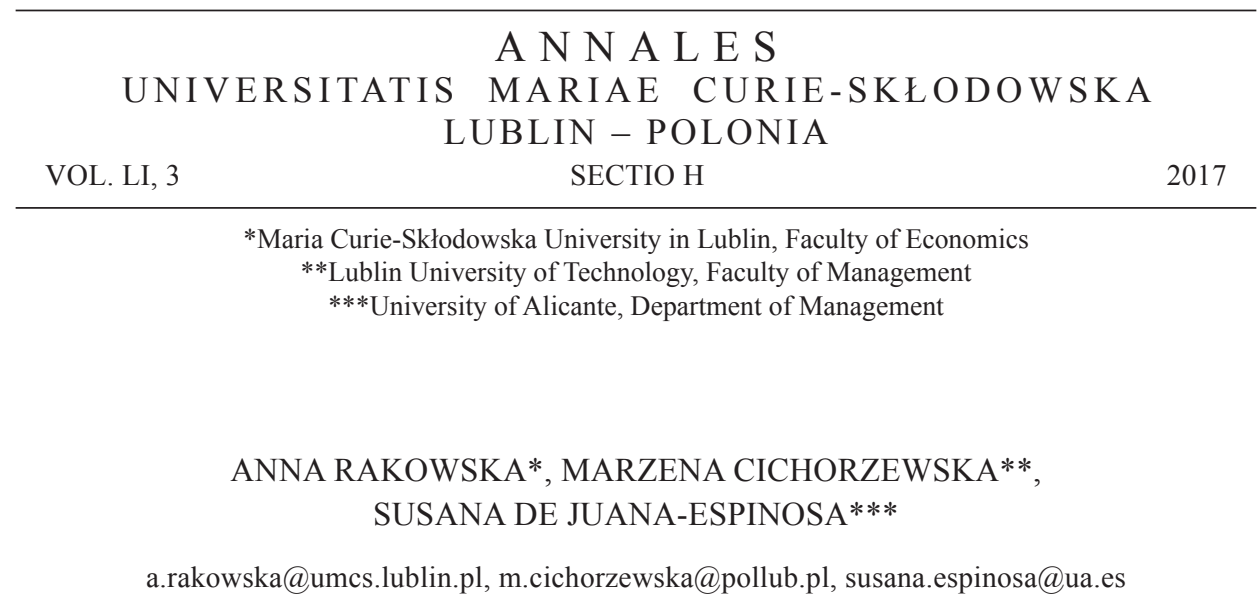

\title{
Satisfaction and Organizational Commitment of Employees of Local Administration - Results of Pilot Studies
}

Satysfakcja i przywiązanie do organizacji pracowników administracji samorządowej

- wyniki badań pilotażowych

Keywords: organizational commitment; job satisfaction; Public Servant Motivation

Słowa kluczowe: przywiązanie organizacyjne; satysfakcja z pracy; motywowanie w administracji publicznej

JEL code: D23; M51; D91

\section{Introduction}

A well-functioning local government is the basis for the development of modern civil society. Due to the criticism of the traditional model of management in administration, European countries have been attempting to implement the idea of New Public Management, which is associated with the application of novel management tools. Studies indicate that efficiency of human resources management in the public sector is much lower than among private businesses [DeSantis and Durst 1996, pp. 327-343]. The phenomenon is justified by the observation that employees of the public sector are characterized by a different motivation than those from the private branch. For example, employees in the public sector are less likely to make decisions involving risk. In addition, at the onset of their careers, their attitude is more pro-social more frequently 
[Buurman et al. 2012, pp. 279-291]. On the other hand, Dur and Zoutenbier [2015, pp. 343-366] observe that employees of the public sector are more altruistic and, at the same time, slightly less vigorous than employees in the private sector.

The assessment of efficiency in human resources management in the public sector is also problematic. On the one hand, a list of indicators and determinants has been established. However, in case of public organizations, some of these may be difficult to apply [Zieliński 2011, pp. 25-34; Moczydłowska 2013, pp. 183-192]. In the science of economy, efficiency denotes the relationship between costs and achievements. In management, the issue of efficiency is discussed in a broader context. Organizational efficiency may be expressed not only in terms of economic but also praxeological factors [Moczydłowska 2013, pp.183-192]. An indirect approach via the identification and assessment of efficiency predictors seems valid. The review of literature proves that satisfaction, job engagement and organizational commitment translate into organizations' financial results [Mackay 2016, pp.1391-1394; Anitha 2014 pp.308-323]. This means that the increase of the engagement and commitment reflects the growth of efficiency in human resources (HR) management.

Satisfaction and HR practices play a significant role in shaping the intensity of job engagement and organizational commitment [Juchnowicz 2010, pp. 57-66; Lewicka 2014, pp. 205-212]. Therefore, the present study will present results pertaining to the level of satisfaction and commitment, and relations of the two variables with actions taken regarding to local administration employees' motivation. The familiarity with these is crucial if they are to be developed properly.

\section{Satisfaction and organizational commitment}

The review of studies in motivation, along with the practice in the field, indicate that job satisfaction constitutes one of the key factors determining employees' behavior, including their work quality and efficiency [Steel et al. 2002]. The satisfaction may be defined as a general attitude of the employed towards their job, which stems from their satisfaction with work and the level of adjustment between the individual and organization. The level of satisfaction is influenced by e.g. working conditions, job security, salary level, relations with colleagues, fair treatment, promotion opportunities [Spagnoli and Caetano 2012].

Studies also strove to determine the relationship between satisfaction, job satisfaction and efficiency. Initially, it was assumed that a direct relationship between job satisfaction and employees' efficiency exists. However, at present, it is believed that job satisfaction and satisfaction with its individual elements do not always contribute to a greater efficiency of employees [Hellriegel and Slocum 2007, p. 57]. However, a correlation between employees' satisfaction and efficiency of the whole organization can be observed [Armstrong 2000, p. 72]. Job satisfaction is perceived as one of the elements enhancing motivation systems [Kopertyńska 2008, p. 247] and 
constitutes a vital factor determining the change of employees' behavior due to the fact that more satisfied employees [Kopertyńska 2008, p. 247; Mrzygłód 2003, p. 2]:

- identify with the organization's objectives to a greater extent;

- exhibit a greater care for work quality;

- are more loyal and committed;

- pose less resistance to change;

- manifest a greater inclination to cooperate with others [Kopertyńska 2008, in: Białas and Litwin 2013, pp. 161-170].

On the other hand, low satisfaction or lack of thereof constitute the reason for counterproductive behaviors, i.e. those harmful to the organization, breaching its rules, and motivating the decline of productivity [Spector and Fox 2005, pp. 151-174; Glińska-Neweś and Lis 2016, pp. 269-273]. The fact that such damaging influence does not pertain to the organization itself is noteworthy. Their consequences encompass a broad range of stakeholders: from owners to suppliers, and business partners [Macko 2010, p. 459].

Apart from satisfaction, the literature of the subject discusses organizational commitment relatively frequently [Brunetto et al. 2012, pp. 428-441; Lewicka 2013 pp. 179-186; Rakowska, Valdes-Conca and de Juana-Espinosa 2014, pp. 5-25]. The literature underlines the importance of organizational commitment due to the conviction that organizations employing committed employees are more efficient because such employees identify with the organization's objectives to a larger extent. There exist several terms describing the phenomenon. Some of them describe it as a "psychological bond linking employees with organizations, which makes resignation less attractive", "a reflection of the level of identification with the organization and commitment towards realization of its objectives", "the desire for maintaining the sense of belonging to an organization, identification with its objectives, successes, and loyalty and readiness for undertaking a significant effort for the sake of the organization", and "a manifestation of positive relations between the employer and employee, where favorable treatment of one is reciprocated by the other side". Studies of Allen and Mayer [Allen and Meyer 1991], who indicated three dimensions of the commitment, played a key role in the development of the idea of organizational commitment [1990, pp. 1-18]:

- affective commitment - based upon employees' emotional approach towards organizations. The approach motivates employees remaining in the organization because of the employment's attractiveness;

- normative commitment - based upon a strong (moral) obligation of employees to remain in the organization;

- continuance commitment - manifested in employees' unwillingness to bear costs associated with a change of their workplace or lack of benefits in case of resignation. The element is heterogeneous and is based upon two elements: negative (so-called continuance attachment) revolving around continuing cooperation based on negative reasons such as high cost associated with the change of a workplace, lack of security, etc., and positive (so-called calcula- 
tive attachment) developed on the basis of benefits gained by the employee [Laguna et al. 2015]. The fact that studies focus primarily on merely two aspects, i.e. those affective and calculative, is noteworthy.

A high level of affective commitment proves employees' strong identification with organizations and voluntary commitment to their issues and problems [Eagunaet al. 2015, pp. 277-228]. Affective commitment is the most valuable to organizations because it contributes to results achieved by employees, stimulates citizenship behavior, and limits fluctuation [Colquitt, LePine, and Wesson 2010]. In addition, Lewicka and Krot [2016, pp. 400-410] indicate a fundamental relation between the affective and calculative aspects.

The level of organizational commitment is determined by several factors. Both external factors, i.e. those associated with work environment, e.g. type of work, employees adjustment to the organization, superiors' support, quality of work environment, and individuals' personal characteristics, can be enumerated. The fact that the more the employee benefits in the course of the exchange, the stronger the organizational commitment becomes, is noteworthy [Lewicka 2017] .

However, it ought to be emphasized that studies frequently focus on two dimensions, i.e. affective and calculative ones [McGee and Ford 1987, pp. 638-641; Shore and Wayne 1993, pp. 774-780]. Such an approach has also been reflected in the present paper.

On the other hand, numerous studies highlight the significance of satisfaction and motivation of public sector employees in light of their commitment [Jae Moon 2000, 177-194]. Behn was the first to pose a question on motivating such employees [Behn 1995, p. 318]. Similarly, Perry and Porter [1982, pp. 89-98] indicated its significance. Motivation in public administration has found reflection in Public Sector Motivation (PSM) [Meyer et al. 2014]. The theory of Public Sector Motivation frequently refers to terms such as "service motivation", "altruism", "helping others", or "prosocial motives". However, the fact that "service motivation" has frequently been applied without a clear definition ought to be emphasized. According to Pearce, service motivation refers to three types of rewards, "»the chance to further the goals of this organization «, »a chance to make a real contribution «, and »identification with the mission of the organization «" [Pearce 1983, p. 649]. In Poland, this issue has been little studied.

On the other hand, a stereotype of a non-motivated civil servant, one manifesting few competences, caring for their own interests, and acting to the detriment of clients, functions worldwide. Therefore, proper understanding of work motivation in local government institutions seems critical for the efficiency and effectiveness of public administration. Studies conducted in 26 countries indicate that on the individual level, public service motivation and extrinsic motivation are both important drivers for this preference. Intrinsic motivation, in turn, is negatively related to people's inclination to work for the public sector. Additionally, having a lower income and lower education is associated with a greater preference for public sector employment [Van de Walle, 
Steijn, and Jilke 2015]. Authors indicate that only small discrepancies are present among individual countries. Therefore, a key question arises: "How to motivate local government employees, and, as a consequence, influence satisfaction and job satisfaction in order for it to translate into organizational commitment and improved work efficiency?". Juchnowicz [2014, pp. 12-13] emphasizes that determinants of satisfaction and job satisfaction ought to be differentiated. As a consequence, job satisfaction is associated with external determinants (e.g. salaries, job security). Satisfaction is associated with internal determinants such as learning opportunities, superiors' recognition. Regardless of the differentiation, a thesis may be posed that satisfaction and job satisfaction are correlated with organizations' motivation systems, and may exert impact upon employees' productivity.

Satisfaction and job satisfaction also influence employees' loyalty towards organizations, and are associated with organizational citizenship behaviors, i.e. development of pro-social attitudes among its employees, which are significant from the point of view of the organization. On the other hand, low job satisfaction is reflected in the lack of acceptance for organizations' values and objectives, and decreases job engagement of employees. Therefore, proper determination of factors influencing satisfaction, motivation, and ultimately, organizational commitment is critical, because organizations ought to care for motivating their employees, in the present case, those employed in local administration.

\section{Results of pilot studies}

Taking the review of literature into consideration as well as the necessity of introducing changes in human resources management in local administration, the following research questions were designed for the purpose of pilot studies:

1) What is the level of job satisfaction of local administration's employees?

2) What is their level of organizational commitment?

3) Which factors determine satisfaction levels?

4) Which factors determine organizational commitment?

In order to obtain answers to these questions, a survey questionnaire was developed. It consisted of 37 items (4 sections) and personal information and demographics. Eight questions pertained to organizational commitment (on the basis of Allen and Meyer concept [1990, pp. 1-18]). Three questions pertained to general satisfaction, 4 were associated with justice ( 2 procedural, and 2 resource-based). Four questions pertained to support (offered by organization, superiors), and 10 questions were connected with motivation system, i.e. being rewarded for particular work achievements. On the basis of the collected data, an analysis of reliability was conducted, i.e. Cronbach's alpha was calculated ${ }^{1}$. Sampling was purposive. Five

1 Cronbach's alpha was larger than 0.7 for each of the scales. 
hundred questionnaires were disseminated to 10 local government institutions in the Lublin region, and 146 were completed and returned. $9.4 \%$ of the sample consisted of managers. The sample was dominated by women $-61 \%$. $67 \%$ of the sample consisted of people aged up to 39 .

Table 1 below contains results pertaining to satisfaction, affective commitment (OC_AF), continuance commitment (OC_CA), perceived procedural justice (PRC_JU), perceived distributive justice (RES_JU), perceived organizational support (SUP_OR), and perceived managers' support (SUP_MN).

Table 1. Results pertaining to satisfaction and organizational commitment

\begin{tabular}{|c|c|c|c|c|c|c|c|}
\hline $\mathrm{N}=146$ & SAT & OC_AF & OC_CA & PRC_JU & RES_JU & SUP_OR & SUP_MN \\
\hline Median & 3.3 & 3.3 & 3.0 & 3.3 & 3.0 & 3.0 & 3.4 \\
\hline SD & 0.4 & 0.7 & 0.5 & 0.7 & 0.8 & 0.8 & 0.8 \\
\hline
\end{tabular}

Source: Authors' own study on the basis of research results.

Results indicate that both satisfaction and organizational commitment are on an average level. This is particularly true for continuance commitment. Therefore, if respondents found a competitive job offer, they would leave their current organization. In addition, median values for affective commitment and satisfaction are low (3.3), i.e. half of results scored below 3.3, and the other half above 3.3. Such a level is not satisfactory and proves low effectiveness regarding human resources management in the studied organizations. Low level of satisfaction, which exerts significant impact upon employees attitudes [Ngo et al. 2014] and behaviors [Demerouti, Halbesleben, and Bakker 2015, pp. 457-469] is particularly alarming. Moreover, organizational support is low as well. Support of superiors was evaluated slightly higher. Support of organizations and managers is particularly vital not only as far as the achievement of good results and development of commitment are concerned, but also regarding the introduction of organizational changes which are critical in some cases [Cullen et al. 2014, pp. 269-280].

In order to assess motivation systems and establish opportunities for satisfaction's improvement, respondents were requested to answer the following question: "How often does your organization grant awards for results and achievements?". The awards included: 1. Pay rise; 2. Job security; 3 . Promotion; 4. More autonomy; 5. Respect from coworkers; 6. Manager's award; 7. Training and Development; 8. New challenges at work; 9. Public recognition; 10. Token (non-financial reward e.g. vouchers, mobile devices). Results are collected in Table 2.

The majority of respondents indicate rewards in the form of job security (median=4), and respect from coworkers (median=4). The following scored the lowest medians: financial (pay rise) and non-financial rewards: tokens (median=1), public recognition (median=2), and promotion (median=2). Even though the lack of financial

\footnotetext{
2 Answers were given based on a Likert scale.
} 
and non-financial rewards can be justified by limited budgets, public recognition for employees' achievements, especially with regard to motivating employees of the so-called "public servants" group, requires considerable improvement [Bozeman and $\mathrm{Su} 2015$, pp. 700-710].

Table 2. Rewards granted for exceptional accomplishments

\begin{tabular}{|c|c|c|c|c|c|c|c|c|c|c|}
\hline & 1 & 2 & 3 & 4 & 5 & 6 & 7 & 8 & 9 & 10 \\
\hline Median & 2.0 & 4.0 & 2.0 & 3.0 & 4.0 & 3.0 & 3.0 & 3.0 & 2.0 & 1.0 \\
\hline SD & 1.1 & 0.9 & 1.0 & 0.9 & 0.8 & 1.2 & 1.0 & 1.0 & 1.1 & 1.0 \\
\hline
\end{tabular}

1. Pay rise; 2. Job security; 3. Promotion; 4. Autonomy; 5. Respect from coworkers; 6. Manager's prize;

7. T\&D; 8. Challenges; 9. Public respect; 10. Token.

Source: Authors' own study on the basis of research results.

In order to obtain answers to the question if awards for exceptional accomplishments are associated with satisfaction and both affective and calculative commitment, the Spearman correlation was calculated. Results are shown in Table 3.

Table 3. Spearman's rank correlation between the studied issues

\begin{tabular}{|c|c|c|c|c|c|c|c|c|c|c|}
\hline \multicolumn{10}{|c|}{ Satisfaction vs. rewards for exceptional accomplishments } \\
\hline 1 & 2 & 3 & 4 & 5 & 6 & 7 & 8 & 9 & 10 & \\
\hline $0.20^{*}$ & $0.24^{* *}$ & $0.24^{* *}$ & $0.20^{*}$ & - & $0.30^{* *}$ & $0.18^{*}$ & $0.18^{*}$ & $0.27^{* *}$ & $0.32^{* *}$ & 1.0 \\
\hline \multicolumn{10}{|c|}{ Affective commitment vs. rewards for exceptional accomplishments } \\
\hline- & $0.35^{* *}$ & $0.29^{* *}$ & $.26^{* *}$ & $0.18^{* *}$ & $0.26^{* *}$ & - & $0.20^{* *}$ & - & $0.21^{* *}$ & 1.0 \\
\hline \multicolumn{10}{|c|}{ Continuance commitment vs. rewards for exceptional accomplishments } \\
\hline- & $0.29^{*}$ & - & - & - & - & - & - & $0.20^{*}$ & $0.17^{*}$ & 1.0 \\
\hline
\end{tabular}

Source: Authors' own study on the basis of research results.

** - statistically significant correlationwith 0.01 value (reciprocal); * - statistically significant correlation with 0.05 value (reciprocal).

When considering satisfaction vs. motivation, three determinants emerge: direct rewards offered by the manager, public recognition, and non-financial rewards. The direct rewards as a factor influencing satisfaction have been confirmed in numerous studies, including those pertaining to the public sector [Azeem and Akhtar 2014, pp. 127-33; Taylor and Westover 2011, pp. 731-751]. In addition, public recognition has also been acknowledged in literature as a factor determining satisfaction of public organizations' employees [Cun 2012, pp. 330-340] and reflects the traditional role of clerks in society. On the other hand, non-financial rewards constitute a form of recognition granted when, due to budgetary limitations, a higher salary is impossible to be offered.

Relationships between satisfaction and organizational support $\left(\mathrm{r}=0.354^{* *}\right)$ and satisfaction and managers' support $\left(\mathrm{r}=0.309^{* *}\right)$ were also established. The existence of such relationships means that, due to low satisfaction levels, there exist possibilities 
of improving the situation by the application of non-financial resources. In addition, the relationship between the perceived distributive justice and satisfaction $\left(\mathrm{r}=0.28^{* *}\right)$ was established. It indicates the possibility of improving satisfaction by introducing and communicating clear procedures of the distribution of organizations' resources. The relationship between satisfaction and affective commitment $\left(\mathrm{r}=0.48^{* *}\right)$, and calculative attachment $\left(\mathrm{r}=0.25^{* *}\right)$ was also determined. However, the latter is weak. In order retain the best employees, it is necessary to find, apart from satisfaction and motivation systems, other factors impacting the two areas.

\section{Conclusions}

Results of the study indicate an average level of satisfaction and commitment of public administration's employees. However, the above-mentioned relationships allow room for improvement to be observed. Such an improvement ought to be sought in shaping good superior-subordinate relationships. In addition, the increase of satisfaction and human resources management improvement ought to be highlighted as well. Results of studies by Szumowski [2014] indicate the necessity of further research on the issue and the introduction of further changes. These results prove that team-spirit atmosphere, job security, job satisfaction, and relations with superiors constitute the most important areas. In addition, bonuses and financial rewards, basic salary, access to trainings, prestige associated with the employment in public institutions, and finally, development and promotion opportunities, are also of significance. The cited results along with results of the present study acknowledge that rather than finances and professional development opportunities, civil servants are motivated by team-spirit atmosphere, job satisfaction and relations with superiors. Such a high position of the atmosphere in the hierarchy of motivators proves that civil servants strive to satisfy social needs at their workplaces. On the other hand, the significance of job security may be associated with a frequent practice of civil law contract employment or frequent political changes.

Lower position of financial motivators probably ensues from the lack of financing opportunities resulting from limited budgets. The situation is prevalent in numerous local government institutions in many countries. It is not financial factors which determine the decision on employment or continuance of employment in public administration. It is rather the work itself and, primarily, job security which provide a stimulus for remaining in the organization. The phenomenon seems to be acknowledged by relatively low scores pertaining to prestige and development and promotion opportunities [Szumowski 2014].

The review of literature and results of pilot studies clearly indicate the need for further research on the issue, mainly due to the necessity of introducing changes in human resources management in public administration. In addition, the present state of research on human resources management in Polish literature is very modest. An 
interesting area to be investigated is whether, when deciding on employment, Polish public administration clerks identify with the image of the Public Servant, and whether their attitude changes overtime. The role of managers in shaping engagement and commitment, along with the perception and efficiency of HRM practices are also worth investigating.

Due to the necessity of regaining trust for public institutions, whose image has been tainted in recent years, the opportunity for shaping Organizational Citizenship Behaviors ought to be emphasized. The remedy for the current state of affairs is seen in the reestablishment of values associated with public services, and them being accepted anew by citizens. This, in turn, will translate into a change of behaviors and contribute to the improvement of the administration's image. In addition, whether clerks are much dedicated to their work, and if they can be well motivated when their organizations' budgets are limited, constitute areas worth further insights. Moreover, enquiries ought to be made into whether New Public Management entails the necessity of developing new premises regarding attitudes and motivation among public organizations' employees.

\section{Bibliography}

Allen, N.J., Meyer, J.P., The Measurement and Antecedents of Affective, Continuance and Normative Commitment to the Organization, "Journal of Occupational Psychology" 1990, vol. 63.

Anitha, J., Determinants of Employee Engagement and Their Impact on Employee Performance, "International Journal of Productivity and Performance Management" 2014, vol. 63, no. 3.

Armstrong, M., Zarządzanie zasobami ludzkimi, Dom Wydawniczy ABC, Kraków 2000.

Azeem, S.M., Akhtar, N., Job Satisfaction and Organizational Commitment among Public Sector Employees in Saudi Arabia, "International Journal of Business and Social Science" 2014, vol. 5, no. 7.

Behn, R.D., The Big Questions of Public Management, "Public Administration Review" 1995, vol. 55, no. 4. Białas, S., Litwin, J., Kierunki badań nad satysfakcją z pracy, “Organizacja i Kierowanie” 2013, no. 3/(156).

Bozeman, B., Su, X., Public Service Motivation Concepts and Theory: A Critique, "Public Administration Review" 2015, vol. 75, no. 5.

Brunetto, Y., Teo, S., Shacklock, K., Farr-Wharton, R., Emotional Intelligence, Job Satisfaction, Well-Being and Engagement: Explaining Organisational Commitment and Turnover Intentions in Policing, "Human Resource Management Journal" 2012, vol. 22, no. 4.

Buurman, M., Delfgaauw, J., Dur, R., van den Bossche, S., Public Sector Employees: Risk Averse and Altruistic?, "Journal of Economic Behavior \& Organization" 2012, vol. 83, no. 3.

Colquitt, J.A., LePine, J.A., Wesson, M.J., Organizational Behavior: Essentials for Improving Performance and Commitment, McGraw-Hill Irwin, New York 2010.

Cullen, K.L., Edwards, B.D., Casper, W.C., Gue, K.R., Employees' Adaptability and Perceptions of Change-Related Uncertainty: Implications for Perceived Organizational Support, Job Satisfaction, and Performance, "Journal of Business and Psychology" 2014, vol. 29, no. 2.

Cun, X., Public Service Motivation and Job Satisfaction, Organizational Citizenship Behavior: An Empirical Study Based on the Sample of Employees in Guangzhou Public Sectors, "Chinese Management Studies" 2012, vol. 6, no. 2.

Demerouti, E., Halbesleben, J.R.B., Bakker, A.B., Productive and Counterproductive Job Crafting: A Daily Diary Study, "Journal of Occupational Health Psychology” 2015, vol. 20, no. 4. 
DeSantis, V.S., Durst, S.L., Comparing Job Satisfaction among Public- and Private-Sector Employees, "The American Review of Public Administration" 1996, vol. 26, no. 3.

Dur, R., Zoutenbier, R., Intrinsic Motivations of Public Sector Employees: Evidence for Germany, "German Economic Review" 2015, vol. 16, no. 3.

Glińska-Neweś, A., Lis, A., Paradoks współwystępowania organizacyjnych zachowań obywatelskich i kontrproduktywnych, Prace Naukowe Uniwersytetu Ekonomicznego we Wrocławiu, 2016, no. 422, DOI: $10.15611 / \mathrm{pn} .2016 .422 .22$

Hellriegel, D., Slocum, J.W., Organizational Behavior, Thomson Learning, USA 2007.

Jae Moon, M., Organizational Commitment Revisited in New Public Management: Motivation, Organizational Culture, Sector, and Managerial Level, "Public Performance \& Management Review" 2000, vol. 24 , no. 2 .

Juchnowicz, M., Zarządzanie kapitałem ludzkim a poziom zaangażowania pracowników, "Zarządzanie Zasobami Ludzkimi” 2010, no. 3-4.

Juchnowicz, M., Satysfakcja zawodowa pracowników. Kreator kapitału ludzkiego, PWE, Warszawa 2014.

Kopertyńska, M.W., Motywowanie pracowników. Teoria i praktyka, Placet, Warszawa 2008.

Lewicka, D., Krot, K., Determinanty satysfakcji i zaangażowania w prace, "Marketing i Rynek” 2016, no. 3 (CD).

Lewicka, D., The Influence of Organizational Trust upon Affective and Calculative Commitment, "The Journal of American Academy of Business", Cambridge 2014, vol. 20, no. 1.

Lewicka, D., Wpływ zaufania wertykalnego na zaangażowanie organizacyjne pracowników, "Acta Universitatis Lodziensis, Folia Oeconomica” 2013, vol. 282.

Lewicka, D., Przywiązanie organizacyjne w zróżnicowanych pokoleniowo grupach pracowników, “Zarządzanie Zasobami Ludzkimi” 2017, no. 3-4.

Łaguna, M., Mielniczuk, E., Żaliński, A., Wałachowska, K., Przywiązanie do organizacji i zaangażowanie w prace-koncepcje teoretyczne i problemy terminologiczne, "Medycyna Pracy” 2015, vol. 66, no. 2.

Mackay, M.M., The Link Between Employee Attitudes and Employee Effectiveness: Data Matrix of Meta-Analytic Estimates Based on 1161 Unique Correlations, "Data In Brief” 2016, vol. 8, published by Elsevier Inc, http://Creativecommons.Org/Licenses/By/4.0/ [access: 25.06.2017].

Macko, M., "My” $i$ “oni”” w organizacjach. Poczucie niesprawiedliwości organizacyjnej a kontrproduktywność pracowników, [in:] T. Listwan, A. Witkowski (eds.), Menedżer w gospodarce opartej na wiedzy, Prace Naukowe UE we Wrocławiu no. 115, Wrocław 2010.

McGee, G.W., Ford, R.C., Two (or More?) Dimensions of Organizational Commitment: Reexamination of the Affective and Continuance Commitment Scales, "Journal of Applied Psychology" 1987, vol. 72, no. 4, http://dx.doi.org/10.1037/0021-9010.72.4.638

Meyer, R.E, Egger $\square$ Peitler, I., Höllerer, M.A., Of Bureaucrats and Passionate Public Managers: Institutional Logics, Executive Identities, and Public Service Motivation, "Public Administration" 2014, vol. 92 , no. 4 .

Meyer, J.P., Allen, N.J., A three-component conceptualization of organizational commitment, "Human Resource Management Review" 1991, vol. 1, no. 1, pp. 61-89, http://dx.doi.org/10.1016/10534822(91)90011-Z

Moczydłowska, J.M., Efektywność zarządzania kapitałem ludzkim jako element efektywności organizacyjnej, [in:] M. Cisek, A. Marciniuk-Kluska (eds.), Efektywność organizacji, Wydawnictwo STUDIO EMKA, Warszawa 2013.

Mrzygłód, J., Badanie postaw i satysfakcji pracowników, "Personel” 2003, no. 22.

Ngo, H.Y., Foley, S., Ji, M.S., Loi, R., Work Satisfaction of Chinese Employees: A Social Exchange and Gender-Based View, "Social Indicators Research" 2014, vol. 116, no. 2, Springer, https://link.springer. com/article/10.1007/s11205-013-0290-2 [access: 25.04.2017].

Pearce, J.L., Job Attitude and Motivation Differences between Volunteers and Employees from Comparable Organizations, "Journal of Applied Psychology” 1983, vol. 68, no. 4. 
Perry, J.L., Porter, L.W., Factors Affecting the Context for Motivation in Public Organizations, "The Academy of Management Review" 1982, vol. 7, no. 1.

Rakowska, A., Valdes-Conca, J., de Juana-Espinosa, S., Affecting Factors of Public Employees' Organizational Commitment, "International Journal of Research and Synergy" 2014, no. 4.

Shore, L.M., Wayne, S.J., Commitment and Employee Behavior: Comparison of Affective Commitment and Continuance Commitment with Perceived Organizational Support, "Journal of Applied Psychology" 1993, vol. 78, no. 5, http://dx.doi.org/10.1037/0021-9010.78.5.774

Spagnoli, P., Caetano, A., Personality and Organisational Commitment. The Mediating Role of Job Satisfaction During Socialisation, "Career Development International" 2012, vol. 17, no. 3.

Spector, P.E., Fox, S., Counterproductive Work Behavior: Investigation of Actors and Targets, APA Books, Washington, D.C. 2005.

Steel, R.P., Griffeth, R.W., Hom, P.W, Lyons, D.M., Practical Retention Policy for the Practical Manager, "The Academy of Management Executive" 2002, vol. 16, no. 2.

Szumowski, W., Motywowanie i satysfakcja z pracy w urzędach administracji samorzadowej. Wyniki badań empirycznych, "Nauki o Zarządzaniu Management Sciences" 2014, no. 3(20), DOI:10.15611/ noz.2014.3.06

Taylor, J., Westover, J.H., Job Satisfaction in the Public Service. The Effects of Public Service Motivation, Workplace Attributes and Work Relations, "Public Management Review" 2011, vol. 13, no. 5.

Van de Walle, S., Steijn, B., Jilke, S., Extrinsic Motivation, PSM and Labour Market Characteristics: A Multilevel Model of Public Sector Employment Preference in 26 Countries, "International, Review of Administrative Sciences" 2015, vol. 81, no. 4.

Zieliński, W., Efektywność ZZL w sektorze publicznym, "Zarządzanie Zasobami Ludzkimi” 2011, no. 3-4.

\section{Satisfaction and Organizational Commitment of Employees of Local Administration - Results of Pilot Studies}

The authors try to describe determinants of job satisfaction and organizational commitment of local government employees. On the basis of the review of literature, it can be concluded that there are a few studies in the area of commitment of public administration employee in Poland. This article consists of two parts. The first one describes the role of job satisfaction as factor influencing different employee organizational behaviors, and explains the relationship among job satisfaction, organizational commitment, and selected elements of motivational system. The second part presents the results of the study carried out among 146 Polish officials from the Lublin region. The results relate to the level of satisfaction and organizational commitment, and their relationships with the ten motivational factors. Conclusions are consistent with literature findings. Polish respondents have a low level of job satisfaction and organizational commitment. The observed relationships of those variables with chosen elements of the motivational system indicate possibilities of changing the situation in local administration in Poland. It mostly refers to focusing on the atmosphere in workplace, and development of good relationships between managers and employees. Authors postulate the need for further research in this area.

\section{Satysfakcja i przywiązanie do organizacji pracowników administracji samorządowej - wyniki badań pilotażowych}

Autorki podjęły się próby scharakteryzowania determinantów satysfakcji i przywiązania organizacyjnego pracowników administracji samorządowej. Na podstawie przeglądu literatury można wnioskować, że mało jest badań dotyczących przywiązania urzędników administracji publicznej w Polsce. Artykuł składa się z dwóch części. W pierwszej opisano znaczenie satysfakcji w kształtowaniu zachowań pracowników $\mathrm{w}$ organizacji oraz wskazano na relacje między satysfakcją, przywiązaniem, a wybranymi elementami systemu motywacyjnego. W drugiej przedstawiono wyniki badań przeprowadzonych wśród 146 urzędników 
Pobrane z czasopisma Annales H - Oeconomia http://oeconomia.annales.umcs.pl

Data: 26/04/2023 09:31:23

z terenu Lubelszczyzny. Wyniki odnoszą się do poziomu satysfakcji i poziomu zaangażowania oraz ich związków z 10 czynnikami systemu motywacyjnego. Są one zbieżne z wynikami zawartymi w literaturze. Polscy respondenci wykazali się niskim poziomem satysfakcji i przywiązania do organizacji. Zaobserwowane związki z elementami systemu motywacyjnego wskazują na możliwości kształtowania poziomu satysfakcji i przywiązania pracowników administracji samorządowej. Dotyczy to przede wszystkim dbałości o właściwą atmosferę pracy i rozwój dobrych relacji między przełożonymi a pracownikami. Autorzy postulują zasadność prowadzenia dalszych badań w tym obszarze. 